\title{
License Revocation of Insurance Companies and Legal Protections of the Policyholders
}

\author{
Ayup Suran Ningsih ${ }^{1}$ \\ ${ }^{1}$ Faculty of Law, Universitas Negeri Semarang, Indonesia \\ ayuupp@gmail.com
}

\begin{abstract}
Introduction to The Problem: Revocation of insurance company business licenses certainly has an effect on the insured as consumers who must be protected. In this case, OJK oversees the flow of revocation of business licenses, which requires insurance companies to report settlement of corporate obligations.
\end{abstract}

Purpose/Objective Study: This research discussed the types of license revocation of the insurance companies and legal protections of the policyholders when this revocation happened.

Design/Methodology/Approach: This study is a qualitative one, which uses a normative juridical method. It approached by the juridical research that uses primary data in the form of Acts or Regulations.

Findings: The types of business license revocation of insurance companies are divided into 4, namely: (1) cancellation of business licenses due to administrative sanctions that are gradually applied; (2) revocation of business licenses due to company requests; (3) dismissal of business licenses due to bankruptcy, and; (4) revocation of business licenses due to the merging or business combination. The respective procedures are governed by the relevant OJK Regulations. The repeal of insurance company business licenses certainly has an effect on the insured as consumers who must be protected. In this case, OJK oversees the flow of revocation of business licenses, which requires insurance companies to report settlement of corporate obligations.

Paper Type: Research Article

Keywords: Business License; Revocation; Insurance Company, Policyholders

\section{Introduction}

In this modern world, people tend to avoid risky things in their life, such as uncertain conditions (evenemen). The threat can occur to anyone because it is placed side by side in daily human activities. It has a speculative nature that is the possibility of losses and gains (Disemadi \& Prananingtyas, 2019). The existence of insurance is one of the applications to overcome the uncertain circumstances that lead to damages. It is an agreement between two parties; both are the insurance company and the policyholder. The contract is giving premiums to the insurance company and providing compensation to the insured because of certain losses due to the uncertain event (Hartono, 1997). 


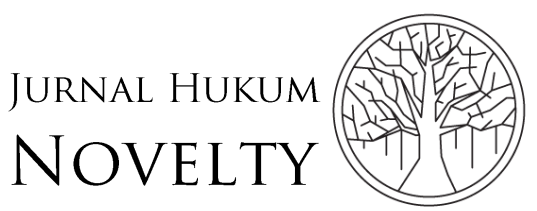

Volume 11, Issue 01, 2020, pp. 95-104

Insurance, in this case, acts as a risk transfer from individual humans to insurance companies that are bounded by agreement. However, not all insurance companies capable enough to avoid risks. It is due to, for example, the insurance bankruptcy, so the claims made by the policyholder cannot be claimed or unpaid (Putriyanti \& Wijayanta, 2010). As a result of not fulfilling the agreement between the policyholder and the insurance company, the Indonesian Financial Service Authority (i.e., Otoritas Jasa Keuangan, abbreviated as OJK) can take actions that lead to the imposition of business sanctions.

The implication of the default can result in the revocation of the insurance company's business license. Such a consequence happened to PT Bakrie Life Insurance, where OJK decide to revoke the company license through the OJK's Board of Commissioners' Decision No. Kep-76/D.05/2016. The cancellation of the company license is due to its incapability to overcome the faced-problems. Judging from the several 0JK's Regulations, such as the Regulation No. 28/POJK.05/2015, No. 24/POJK.04/2016, and No. 17/POJK/05/2017, we know that the revocation of the insurance company license is not based on only one factor, but many.

The factor diversities for revocation of an insurance company business license also have its procedure on how the license cancellation will occur. Additionally, to discuss the types and systems for revoking the permit, this article will also seek the legal protection form for the insured as a customer when the insurance company has no more license due to the company's default. Based on this background, the arising problems are what is the type and procedure for the revocation of insurance company's permission and how the legal protection of the insured due to the company's default should occur.

\section{Methodology}

The method used in this article is qualitative through the type of normative juridical research. It is research that focuses on particular Acts or Regulations. Thus, the primary data used in this study are OJK's Regulation No. 28/POJK.05/2015, No. 24/POJK.04/2016, and No. 17/POJK/05/2017. While for secondary data, this article used the kinds of literature relating to research substance. This research is focused on finding out the type and procedure of revocation of an insurance company's business license. Second, to determine the legal protection of the insured after the dismissal of the insurance company's business license.

\section{Results and Discussion}

\section{The types and Procedures for Revocation of Insurance Business License}

Based on Article 6, one of OJK's authorities in its supervisory function is revoking the business license. Revocation of insurance company business licenses carried out by OJK based on several factors and reasons. There are four types of revocation of business licenses of companies in the financial sector: 
1. Revocation of business licenses due to business sanctions (administrative sanctions) reviewed from OJK's Regulation No. 17/POJK.05/2017;

2. Revocation of business licenses due to bankruptcy requests that will be in terms of OJK's Regulation No.28/POJK.05/2015;

3. Revocation of business licenses due to company requests reviewed from OJK's Regulation No. 28/POJK.05/2015;

4. Revocation of insurance company licenses due to consolidation reviewed from OJK's Regulation No. 24/POJK.04/2016.

\section{Revocation of Business License Due to Business Sanctions}

One of OJK's authorities is to set administrative sanctions. Types of administrative penalties that can be imposed on violators are the prohibition to market insurance products for specific business lines, written warnings, restrictions on business activities for some or all business activities, administrative fines, revocation of business licenses (Ningsih, Suprapti, \& Fibrianti, 2019). These administrative penalties are based on Article 71 paragraph (2) of Act No. 40 of 2014 concerning Insurance and Article 2 paragraph (2) of OJK's Regulation No. 17/POJK.05/2017.

Meanwhile, Article 77 of OJK's Regulation No. 69/POJK.05/2016 regulates the factors of administrative sanctions imposed by OJK on Insurance Companies. The Revocation of a business license is a form of administrative punishment that can be applied by the 0JK. Imposing administrative sanctions until the revocation of business license to the Insurance Company is carried out in the below stages:

First is written warning. The written notice will be given three times in a row to the insurance company. The warning is regulated in Article 3 paragraph (1) of OJK's Regulation No. 17/POJK.05/2017. The procedure of the notice is when after the first written warning, the insurance company is unable to overcome the violation, will then, the second written warning is given. The third notice will be sent to the company if the second one is not applied until the specified period (Apriani, 2018; Ningsih \& Disemadi, 2019; Setiawati, 2018).

The period of administrative sanctions in the form of written warnings for the Insurance Company is 30 days after each stipulation of the administrative penalties. But administrative sanctions may be applied longer than 30 days or six months for the maximum time if the OJK considers that the types of violations committed may not be able to be resolved within 30 days. It is due to the unfulfilling the minimum level of solvency or minimum equity requirements or administrative sanctions for not meeting the minimum equity requirements. While in exception, the giving time is three months for other cases than those mentioned (Abubakar \& Sukmadilaga, 2017).

OJK's Regulation No. 17/POJK.05/2017 divides the form of restrictions on insurance company business activities into two, namely administrative sanctions in the form of suspension of some business activities and suspension of all business activities. The period of administrative penalties in the way of suspension of business activities for 


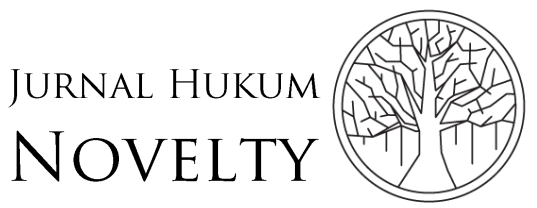

Volume 11, Issue 01, 2020, pp. 95-104
P-ISSN: $1412-6834$

E-ISSN: 2550-0090

insurance companies is no later than one year from the stipulation of the administrative sanctions.

Imposing administrative sanctions in the form of suspension of business activities must not be preceded by the imposition of the written warning. It occurs under particular conditions, such as an unhealthy financial condition that endangers the insured. Such a term legalizes the OJK to pass the written notice along with the restriction of business activities. For public information, OJK must announce the sanctions through the OJK's website (Diba, Disemadi, \& Prananingtyas, 2020).

Second is the revocation of insurance business License. The penalty is given when the insurance company is unable to overcome violations that cause the company to be subject to the restriction on business activities. It is in line with Article 72 paragraph (2) of the Insurance Act. Based on Article 6 paragraph (2) of OJK's Regulation No. 17/POJK.05/2017, OJK regulates the dismissal of business licenses without prior written notification or restricts the business activities if the insurance company has a deteriorating financial condition. For example, the level of solvency of the insurance company is drastically decreasing within one year or less, so it down below the minimum limit (Abubakar \& Sukmadilaga, 2017).

Examples of revocation of business licenses in the insurance sector are revocation of business licenses in the field of life insurance for PT Asuransi Jiwa Bakrie through OJK's Board of Commissioners' Decision No. Kep-76/D.05/2016. The dismissal of PT Asuransi Jiwa Bakrie's permit is following OJK's Regulation No. 17/POJK.05/2017. The consequences arising from the revocation of the PT Asuransi Jiwa Bakrie's license are:

1. The insurance company is prohibited from conducting business activities in specific insurance fields;

2. Directors, Board of Commissioners, Shareholders, and employees are prohibited from transferring, pledging, using the company's wealth, or other actions that can reduce the company's assets;

3. Arrange and submit a closing balance sheet to 0JK for 15 days maximum from the license revocation.

\section{Revocation of Business Permits Due to Bankruptcy}

Apart from administrative sanctions, another type of annulment is due to the insolvency of the insurance company. Creditors are parties who can request bankruptcy through 0JK from the Commercial Court if the insurance company is in an insolvency condition. Based on OJK's Regulation No.28/ POJK.05/2015, the procedure of this license dismissal are:

First, requesting for bankruptcy status to the Commercial Court. Based on Article 52 of the Regulation and its evaluation, the creditor may submit a request for bankruptcy if it meets the declared bankrupt requirements. This request is presented by the creditor to the $0 \mathrm{JK}$, and then the $0 \mathrm{JK}$ sends the request to the commercial court. The 
application submitted must contain the identity of the creditor, the name of the insurance company concerned, the basic description of the form, and the thing requested to be severed. They all must be accompanied by supporting evidence (Abubakar \& Sukmadilaga, 2017). Application letter addressed to the Chairperson of the OJK Board of Commissioners, and a copy to the Chief Executive of Insurance Supervisory, Pension Funds, Financing Institutions, and OJK (Setiawati, 2018).

Second is an examination of bankruptcy requests by OJK. If there is an incomplete request, OJK notifies the creditor to complete it for a maximum of 10 days. If the application is passed the deadline, then the application is considered null, and 0JK returns the file to the creditor. If it completes, the OJK will decide to approve or reject the application no later than 30 days after the complete request is received. Consideration of refusing or accepting an application for an Insurance Company bankruptcy is contained in Article 55 paragraph (1) of the Regulation.

The rejection of a bankruptcy request is submitted by the 0JK, with the reasons for refusal to the creditor. In this case, the OJK can advise the creditor to settle the dispute through the Alternative Dispute Resolution Institution or in a civil/peaceful settlement of disputes. While the approval of bankruptcy request is submitted by the OJK to the commercial court, the cost is borne by the commercial court, and an application for an Insolvency Insurance Company can be filed by OJK without a creditor's request following the Article 56 paragraph (2) of the Regulation.

The third is the determination of bankruptcy and revocation of insurance business company licenses. If the assets of an insured company declared bankrupt is in an insolvency condition and the bankruptcy of the assets is administered, the provisions regarding the distribution of Company assets are in liquidation. As referred to Article 24 to Article 28, mutatis mutandis will be applied to the placement of the declaredbankrupt company assets. If the issuance of insurance company assets declared bankrupt has been carried out and the bankruptcy of the company ends, the next step taken by $0 \mathrm{JK}$ is to revoke the business license of the relevant company. One example of revoking an insurance company business license due to bankruptcy is the 0JK's Board of Commissioners Decree No. KEP-12/D.05/2013 concerning revocation of PT Asuransi Jiwa Bumi Asih Jaya's business license.

\section{Revocation of Business License Due to Company Requests}

One of the factors to revoke other business licenses other than due to business sanctions and bankruptcy of an insurance company is based on the request of the company concerned. It is regulated in article 43 of OJK's Regulation No. 28/POJK.05/2015, where companies that stop their business activities must report their termination plans to OJK first. Some requirements must be fulfilled by companies for their planning to end their business activities. The procedure for revoking business licenses due to company requests are: 


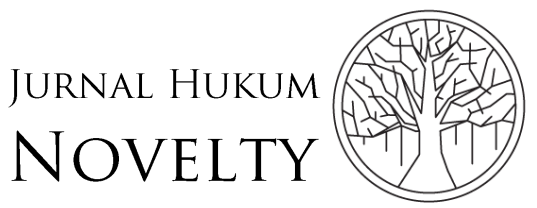

Volume 11, Issue 01, 2020, pp. 95-104
P-ISSN: 1412-6834

E-ISSN: 2550-0090

1. They are reporting the plan to terminate the business activities to OJK. The plan to cease the business activities of a company shall be submitted by the Board of Directors to OJK.

2. Obtain approval from $0 \mathrm{JK}$ based on the reasons for the termination, company conditions, plan for resolving the company's obligations to all creditors. The dissolution plan after completing its requirements is in accordance with Article 44 paragraph (2), as well as documents that must be attached in accordance with the mandate of Article 44 paragraph (3).

3. OJK examines plans to terminate business activities. OJK, based on the results of its research, issued a letter containing the approval or rejection of the plan no later than 30 days from the receipt of a complete plan to terminate business activities. If the termination plan is approved by the $0 \mathrm{JK}$, the company has obligations that must be carried out, namely ceasing all business activities of the company; announce it in the newspaper no later than ten days from the approval of the termination plan and the announcement is made for three consecutive days; completing all company obligations a maximum of four months; and compile a final balance sheet to ensure the completion of all the responsibilities of the company have been fulfilled and no party is harmed by the termination of a company's business activities.

4. Reporting to the OJK. This report is submitted after all obligations stated in Article 46, OJK's Regulation No. 28/POJK.05/2015 have been completed by the company.

5. Investigating the report submitted by the company's Directors. Within a maximum of 30 days, a decree was issued regarding the revocation of the company's business license after the OJK received the report.

6. The final stage is the issuance of the license dismissal of the company business.

\section{Revocation of Business Licenses due to Smelting or Merging}

Another type of cancellation of licenses additional than mentioned before is a revocation of business licenses due to business consolidation or business combination. The definition of business consolidation based on OJK's Regulation No. 74/POJK.04/2016, Article 1 paragraph (3) is legal actions carried out by two or more companies by merging into one new company, which due to the law, could obtain assets, liabilities, and equity from the merged-company. While the definition of a business combination is contained in Article 1 paragraph (2), which is a legal action carried out by one or more companies to merge with other existing companies. The procedures for combining or consolidating a business are:

1. Compiling the plans of a business combination or business consolidation. The program itself proposed by the Board of Directors of each company and must be approved by each company's Board of Commissioners. The project must follow the regulated-rules in Article 4 of OJK's Regulation No. 74/POJK.04/2016. Besides, there must be a clear statement that the merger or amalgamation of the business is carried out by taking into account several things mandated in Article 5, namely company interests, public interests, fair competition in conducting business, 
guarantees the fulfillment of the obligations of shareholders and employees (Setiawati, 2018). After that, the public company announces the summary of the merger project draft no later than the end of the $2^{\text {nd }}$ working day after obtaining the approval of the Board of Commissioners and 30 days before the General Meetings of Shareholders (GMS) summons to the public through the local daily newspaper or the stock exchange website and website public company;

2. Proof of the announcement must be submitted to the OJK no later than two working days after the publication;

3. After 20 days, the company approved for the merger and the consolidation of its business to the competent authority. The company's merger must be reported to the OJK;

4. Report the opening of a new office to OJK;

5. OJK revokes company business licenses that combine businesses or merge businesses.

One example of a company whose business license was revoked due to a merger was the revocation of PT AXA Life Indonesia's (ALI) business permit. The dismissal itself recorded through OJK's Board of Commissioners Decree No. KEP-2/D.05/2018 as part of the merger of PT AFI and PT ALI, which has approved from OJK. The business alliance, then, has a legal consequence that is the revocation of a business license of a company.

\section{Legal Protection of Insured for Revocation of Business License Insurance Companies}

Dismissal of an insurance company business license must have implications or impacts on customers as an insurance policyholder. To protect consumers regarding the consequences caused by the cancellation of an insurance company's business license, we can review it from the regulations in force in Indonesia. Article 4 of Act No. 8 of 1999 mandates the rights possessed by consumers, including consumers in the financial industry sector, such as insurance businesses. Other than the previous Act, there is also the Act No. 40 of 2014 as a lex specialis derogate legi generali from other related regulations in the insurance business sector for consumer protection after the revocation of an insurance company business license. In the case of dismissal of an insurance company business license, 0JK's existence is to protect consumers in the financial services sector, including the insurance industry (Setiawati, 2018). 0JK, which has supervisory and regulatory functions, also prioritizes consumer protection in making regulations regarding the procedures for revoking business licenses of insurance companies (Attamimi, Disemadi, \& Santoso, 2019). Such a priority can be explicitly seen in OJK's Regulation No.74 / POJK.04 / 2016 Article 5. The regulation will force the company to fulfill the obligations of shareholders or consumers before its business license is revoked (Ikram, Njatrijani, \& Lestari, 2016).

Meanwhile, Act No. 40 of 2014 formulates Article 52 to protect consumers affected by the revocation of insurance company business licenses. The article states that if an 


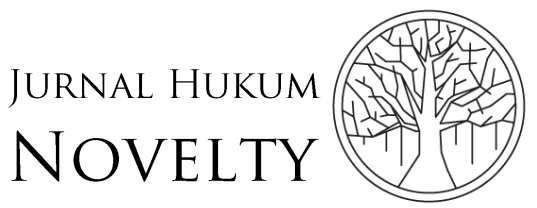

Volume 11, Issue 01, 2020, pp. 95-104
P-ISSN: $1412-6834$

E-ISSN: 2550-0090

insurance company is bankrupt or liquidated, the rights of the Policy Holder, Insured, or Participant in the distribution of their assets have a higher position than the rights of other parties and the insurance fund. The assets must first be used to fulfill the policyholders' rights, the insured, or other parties entitled to insurance benefits (Hermawati, 2016). If there is an excess of the insurance fund after fulfillment, the excess can be used to fulfill the obligations to third parties other than the policyholder, the Insured, or other parties entitled to insurance benefits.

Thus, based on Article 52 of Act No. 40 of 2014, policyholders have a higher position or payment priority when an insurance business license is revoked because of bankruptcy (Rahardjo, 2018). Additionally, this Act also mandates the insurance companies to participate in the policy guarantee program following Article 53 of the Law on Insurance. Through the policy guarantee program, public interest and trust will increase toward the insurance company. It is because the policy guarantee program is an effort to guarantee the return of consumers or policyholders' rights when insurance company unable to do their business due to bankruptcy. The Act also forces the insurance company, as stated in Article 54, to become members of mediation institutions that have the function of dispute resolution (Husain, 2016).

OJK, as in Act No. 21 of 2011, Article 29, must provide consumer complaint services where 0JK can carry out verification and distinctive examination of the referred complaints. OJK must also facilitate the settlement of consumer complaints that have been disadvantaged by financial services actors, including those in the insurance sector (Ikram, Njatrijani, \& Lestari, 2016). Article 30 of this Act also authorizes OJK to order or take specific actions to the financial services institutions to resolve consumer complaints that have been harmed to protect consumers and the public (Triana, 2016). Also, to order or take specific actions to the companies, OJK is entitled to file a lawsuit for recovering the losses property of the consumer and to obtain compensation. Additionally, OJK's Regulation No. 28/POJK.05/2015 also mandates to form the liquidation team. The company is obliged to stop business activities and immediately hold a GMS to decide on dissolution and build a Liquidation Team since the revocation of the company's business License (Ulya, 2016). The Liquidation Team is a team in charge of liquidation, which is formed by the GMS or 0JK. The team has the task to resolve matters relating to liquidation, resolve issues relating to company employees, submit company assets and liabilities, submit periodic reports, and related reports if necessary to the $0 \mathrm{JK}$. Payment of obligations to creditors from the disbursement of assets can be done in stages or at the same time at the end of the liquidation period as long as it does not violate the laws and regulations and obtain approval from the OJK (Putri \& Rahayu, 2019).

If there are creditors who have not submitted invoices to the Liquidation Team, they can send invoices within two days after the liquidation process has been completed (Prabowo \& Umami, 2018). The bill is submitted through the OJK to shareholders or equivalent to shareholders in legal entities in the form of cooperatives (Surana, 2016). 
Claims arising after the liquidation process will be charged to the remaining liquidation results, which are the rights of shareholders or equivalent to shareholders in legal entities in the form of cooperatives. So, based on the request of shareholders or the equivalent of shareholders in legal entities, the 0JK may request an authorized agency to revoke the blocking of the remaining liquidation proceeds in the amount of the said bill to pay the verified bills. If after the two year period expires and no claims are submitted through the 0JK to the shareholders, 0JK will request the revocation of blocking from the authorized agency for the remaining liquidation proceeds to be taken by shareholders. The condition also occurs when there are claims but are still in liquidation proceeds (Ikram, Njatrijani, \& Lestari, 2016).

\section{Conclusion}

There are four types of business license revocation of insurance companies in Indonesia. The first revocation is due to administrative sanctions. The second revocation is due to the insurance company bankruptcy. The third revocation is due to company requests. The last cancellation is the dismissal of insurance company licenses due to the merging project between companies. Each of the license revocations has a distinctive procedure to be done.

The authority of OJK to be able to revoke the business license does not mean leaving the policyholders behind. It is for sure that the policyholders, as insurance consumers will gain losses when the company they insure to have revoked their business license. Through several Acts and Regulations, the Indonesian Government ensures the consumer to be protected. So, the link between the insurance company and policyholders as the consumer will have mutual benefits from each other.

\section{References}

Abubakar, L., \& Sukmadilaga, C. (2017). Implementasi kepatuhan terhadap prinsip syariah melalui penggunaan polis standar dalam praktik asuransi syariah. Rechtidee, 12(1), 107. https://doi.org/10.21107/ri.v12i1.2852

Apriani, R. (2018). Sanksi hukum terhadap pihak penanggung atas klaim asuransi yang tidak dipenuhi penanggung berdasarkan hukum positif. Syiar Hukum: Jurnal Ilmu Hukum, 16(1). https://doi.org/10.29313/sh.v16i1.5130

Attamimi, Z. F., Disemadi, H. S., \& Santoso, B. (2019). Prinsip Syariah dalam penyelenggaraan bank wakaf mikro sebagai perlindungan hak spiritual nasabah. Jurnal Jurisprudence, 9(2), 117-132. https://doi.org/10.23917/jjr.v9i2.8897

Diba, N. F., Disemadi, H. S., \& Prananingtyas, P. (2020). Kebijakan tata kelola Otoritas Jasa Keuangan (OJK) di Indonesia. Ekspose: Jurnal Penelitian Hukum Dan Pendidikan, 18(2), 868-876. https://doi.org/10.30863/ekspose.v18i2.485

Disemadi, H. S., \& Prananingtyas, P. (2019). Perlindungan hukum terhadap nasabah perbankan pengguna CRM (Cash Recycling Machine). Jurnal Magister Hukum Udayana (Udayana Master Law Journal), 8(3), 286. https://doi.org/10.24843/JMHU.2019.v08.i03.p07

Hartono. (1997). Hukum Asuransi dan Perusahaan Asuransi. Jakarta: Sinar Grafika.

Hermawati. (2016). Perlindungan hukum tertanggung dalam pembayaran klaim asuransi jiwa. TAFAQQUH: Jurnal Hukum Ekonomi Syariah 
Dan Ahwal Syahsiyah, 1(2). Retrieved from http://ejournal.kopertais4.or.id/sasambo/index.php/tafaqquh/article/view/3 047

Husain, F. (2016). Perlindungan Hukum terhadap pemegang polis asuransi menurut UU No. 40 Tahun 2014 tentang Perasuransian. Lex Crimen, 5(6). Retrieved from https://ejournal.unsrat.ac.id/index.php/lexcrimen/article/view/13468

Ikram, F. D., Njatrijani, R., \& Lestari, S. N. (2016). Perlindungan hukum kepada tertanggung PT MAA General Assurance dalam hal dicabutnya izin usaha perusahaan oleh Otoritas Jasa Keuangan (OJK). Diponegoro Law Journal, 5(4). Retrieved from https://ejournal3.undip.ac.id/index.php/dlr/article/view/13740

Ningsih, A. S., \& Disemadi, H. S. (2019). Breach of contract: an Indonesian experience in akad credit of sharia banking. Ijtihad: Jurnal Wacana Hukum Islam Dan Kemanusiaan, 19(1), 89-102. https://doi.org/10.18326/ijtihad.v1i1.89-102

Ningsih, A. S., Suprapti, D. D., \& Fibrianti, N. (2019). The importance of applying the membership value toward savings and loans cooperatives in Indonesia. Sriwijaya Law Review, 3(2). Retrieved from http://journal.fh.unsri.ac.id/index.php/sriwijayalawreview/article/view/235

Prabowo, M. S., \& Umami, Y. Z. (2018). The existence of a company in the society and its legality in Indonesian Law. Journal of Private and Commercial Law, 2(1), 3346. https://doi.org/10.15294/jpcl.v2i1.13962

Putri, D. A., \& Rahayu, S. W. (2019). Mekanisme perlindungan konsumen usaha asuransi oleh Otoritas Jasa Keuangan. Kanun Jurnal Ilmu Hukum, 21(1), 129-144. https://doi.org/10.24815/kanun.v21i1.12412

Putriyanti, E. D., \& Wijayanta, T. (2010). Kajian hukum tentang penerapan pembuktian sederhana dalam perkara kepailitan asuransi. Mimbar Hukum, 22(3). Retrieved from https://journal.ugm.ac.id/jmh/article/view/16240

Rahardjo, I. (2018). Nasib nasabah pasca izin asuransi dicabut. Retrieved December 12, 2019, from CNBC Indonesia website: https://www.cnbcindonesia.com/opini/20180119150856-14-2003/nasibnasabah-pasca-izin-asuransi-dicabut

Setiawati, N. S. (2018). Perlindungan hukum terhadap pemegang polis asuransi dalam menyelesaikan sengketa klaim asuransi. SPEKTRUM HUKUM, 15(1), 150. https://doi.org/10.35973/sh.v15i1.1115

Surana, N. B. (2016). Kajian yuridis perlindungan hukum tertanggung pada perjanjian asuransi kendaraan bermotor di PT. Asuransi Ramayana TBK. Jakarta. Jurnal Idea Hukum, 2(1). https://doi.org/10.20884/1.jih.2016.2.1.27

Triana, M. (2016). Analisis yuridis terhadap polis asuransi kendaraan bermotor pada PT. Asuransi Raya Cabang Medan. Jurnal Mercatoria, 9(1). https://doi.org/https://doi.org/10.31289/mercatoria.v9i1.320.g856

Ulya, I. R. (2016). Perlindungan hukum nasabah pasca pencabutan izin usaha Perusahaan asuransi Jiwa Bumi Asih Jaya (BAJ) oleh Otoritas Jasa Keuangan (OJK) (Universitas Islam Negeri Syarif Hidayatullah Jakarta). Retrieved from http://repository.uinjkt.ac.id/dspace/handle/123456789/30536 